\title{
Studies on Certain Egg Qualities of Indigenous, Vanaraja, and Crossbred (PB2 x Indigenous) Chickens under Intensive and Backyard Systems of Rearing
}

\author{
I.U. Sheikh ${ }^{1 *}$, N. Kalita ${ }^{1}$, J.D. Mahanta ${ }^{1}$ and J. Hussain ${ }^{2}$ \\ ${ }^{1}$ Department of Poultry Science, College of Veterinary Science, Assam Agricultural \\ University, Khanapara, Guwahati-7810 22, India \\ ${ }^{2}$ Department of Livestock Production and Management, Assam Agricultural University, \\ Khanapara, Guwahati-7810 22, India \\ *Corresponding author
}

\section{A B S T R A C T}

A study has been conducted on a total 1200 no. of chicks out of which 600 numbers (200 each of Indigenous, Vanaraja and Crossbred) were reared under intensive system. All the types of chicken were fed uniform diet of Chick (0-8 weeks), Grower (9-20 weeks) and

Keywords

Egg quality, Indigenous, Vanaraja, Crossbred, Intensive, backyard rearing

Article Info

Accepted:

12 March 2018 Available Online:

10 April 2018
Layer (above 20 weeks) ration prepared with conventional feedstuffs as per BIS (1992). Remaining 600 numbers (200 each of Indigenous, Vanaraja and Crossbred) were distributed among 30 beneficiaries for backyard system of rearing. The overall egg weights at 40 weeks of age were significantly $(\mathrm{P} \leq 0.05)$ higher in Vanaraja $(53.65 \pm 0.57 \mathrm{~g})$ followed by Crossbred (44.6 $\pm 0.55 \mathrm{~g})$ and Indigenous $(34.60 \pm 0.28 \mathrm{~g})$ chickens. Similarly the overall egg weights at 40 weeks of age was significantly $(\mathrm{P} \leq 0.05)$ higher under intensive system $(45.10 \pm 1.51 \mathrm{~g})$ than under backyard system $(43.47 \pm 1.34 \mathrm{~g})$ of rearing. The shape index was found to be higher in indigenous than Vanaraja and crossbred chicken. Significantly $(\mathrm{P} \leq 0.05)$ higher values of egg weight, egg shell thickness, egg yolk index and H.U scores of eggs were observed under intensive system of rearing than those under backyard system of rearing. However, rearing systems had no significant effect on shape index and albumen index values of eggs. It can be concluded that the Vanaraja could be reared successfully under backyard system of rearing for increasing egg mass.

\section{Introduction}

Livestock and poultry activities play an important role in national economy and in socio-economic development of the country. Today India is the fifth largest producer of poultry meat in the world with an annual production of 2.47 million MT and third largest producer of eggs with an annual production of 74.75 billion during 2013-14 with the per capita availability of eggs is only 61 and that of poultry meat is $3.1 \mathrm{~kg}$ which is far below the ICMR recommendation of 180 eggs and $11 \mathrm{~kg}$ meat per person per annum (DAH\&FS, 2015). However, despite about 25 per cent of the people living in urban areas consuming 75 per cent of the eggs and almost 100 per cent of the broilers produced in India 
because most of the commercial poultry egg and meat production is concentrated in the urban and semi urban areas. Though, still it is contributing $30 \%$ to the national egg production, the rural backyard poultry is the most neglected one (Tajane and Vasulkar, 2014). The major limiting factor in the way of increasing consumption of egg and poultry meat in the rural area is the poor availability. The demand of eggs and meat of rural areas to be met by backyard poultry rearing (Nandi et al., 2007 and Panda et al., 2008). It is estimated that at about 72 lakh eggs per week are coming to Assam mainly from Andhra Pradesh. Rearing of Vanaraja chicken provides subsidiary income and ensures the availability of egg and chicken meat in the rural and tribal areas. The egg quality is an important factor in economic poultry production. Therefore, the present study was undertaken to evaluate certain egg qualities of Indigenous, Vanaraja and Crossbred chicken under intensive and backyard systems of rearing.

\section{Materials and Methods}

The present study was conducted in the experimental poultry shed under the project AICRP on Poultry breeding, Department of Poultry Science, College of Veterinary Science, Assam Agricultural University, Khanapara, Guwahati-7810 22 for intensive system and in Bijoynagar area of Kamrup district for backyard system. A total 1200 no. of chicks out of which 600 numbers (200 each of Indigenous, Vanaraja and Crossbred) were reared under intensive system. All the types of chicken were fed uniform diet of Chick (0-8 weeks), Grower (9-20 weeks) and Layer (above 20 weeks) ration prepared with conventional feedstuffs as per BIS (1992) throughout the rearing period. Remaining 600 numbers (200 each of Indigenous, Vanaraja and Crossbred) were distributed among 30 beneficiaries for backyard system of rearing.
All the birds were vaccinated and medicated following standard schedule. The birds were reared under intensive and backyard systems up to 52 weeks of age. The standard external and internal egg quality traits were studied at 40 weeks of age under intensive and backyard systems of rearing. The data were analysed statistically as per Snedecor and Cochran (1994).

\section{Results and Discussion}

The mean values various egg quality traits of different types of chicken under intensive and backyard systems of rearing at 40 weeks of age is presented in Table 1 . The overall egg weights at 28, 40 and 52 weeks of age were significantly $(\mathrm{P} \leq 0.05)$ higher in Vanaraja $(46.70 \pm 0.45,53.65 \pm 0.57$ and $55.72 \pm 0.62$ g) followed by Crossbred (37.75 $\pm 0.35,44.6$ \pm 0.55 and $47.20 \pm 0.36 \mathrm{~g})$ and Indigenous $(32.60 \pm 0.27,34.60 \pm 0.28$ and $36.75 \pm 0.26$ g) chickens. Similarly the overall egg weights at 28, 40 and 52 weeks of age was significantly $(\mathrm{P} \leq 0.05)$ higher under intensive system $(39.73 \pm 1.13,45.10 \pm 1.51$ and 47.40 $\pm 1.57 \mathrm{~g})$ than those under backyard system $(38.30 \pm 1.01,43.47 \pm 1.34$ and $45.67 \pm 1.38$ $\mathrm{g})$ of rearing. The overall shape Index was found to be significantly $(\mathrm{P} \leq 0.05)$ higher in Indigenous $(75.33 \pm 0.31)$ followed by Vanaraja (72.38 \pm 0.29$)$ and Crossbred (70.43 \pm 0.25 ) birds.

The overall shell thickness was significantly $(\mathrm{P} \leq 0.05)$ lower in Indigenous $0.335 \pm 0.008$ than Vanaraja $(0.380 \pm 0.004)$ and Crossbred $(0.383 \pm 0.005)$ birds. The overall Yolk Index was significantly $(\mathrm{P} \leq 0.05)$ higher in Indigenous $(0.454 \pm 0.009)$ than Vanaraja $(0.427 \pm 0.004)$ and Crossbred $(0.417 \pm 0.005)$ birds. The overall Albumen Index was recorded as $0.96 \pm 0.003,0.103 \pm 0.004$ and $0.104 \pm 0.006$ for Indigenous, Vanaraja and Crossbred birds, respectively which differed non significantly. 
The mean values various egg quality traits of different types of chicken under intensive and backyard systems of rearing at 40 weeks of age is presented in Table 1 . The overall egg weights at 28, 40 and 52 weeks of age were significantly $(\mathrm{P} \leq 0.05)$ higher in Vanaraja $(46.70 \pm 0.45,53.65 \pm 0.57$ and $55.72 \pm 0.62$ g) followed by Crossbred (37.75 $\pm 0.35,44.6$ \pm 0.55 and $47.20 \pm 0.36 \mathrm{~g})$ and Indigenous $(32.60 \pm 0.27,34.60 \pm 0.28$ and $36.75 \pm 0.26$ g) chickens. Similarly the overall egg weights at 28, 40 and 52 weeks of age was significantly $(\mathrm{P} \leq 0.05)$ higher under intensive system $(39.73 \pm 1.13,45.10 \pm 1.51$ and 47.40 $\pm 1.57 \mathrm{~g})$ than those under backyard system $(38.30 \pm 1.01,43.47 \pm 1.34$ and $45.67 \pm 1.38$ g) of rearing.

The heavier eggs in Vanaraja and Crossbred chicken might be due to their better genetic potential and higher body weight resulting in production of heavier eggs.

The egg weights found in the present study were in agreement with the reports of other workers (Ramana et al., 2010; Kalita et al., 2011a; Gonmei, 2012 and Jha et al., 2012) who recorded significantly $(\mathrm{P} \leq 0.05)$ higher egg weights in Vanaraja than that of the Indigenous chicken. Pathak (2013) also recorded significantly $(\mathrm{P} \leq 0.05)$ higher egg weight in Crossbred (PB2 x Indigenous) than those of Indigenous chicken.

The heavier eggs produced under intensive than those under backyard system might be due to better nutrition and improved care and management of birds under intensive system. The body weight under intensive system was also higher than those under backyard system, which could also add to production of heavier eggs. This was in agreement with the reports of Khan (1996) who recorded heavier eggs under intensive than those under scavenging systems in Indigenous fowl and coloured dwarf layer Krishna-J hens. Doley (2006) also recorded significantly $(\mathrm{P} \leq 0.05)$ higher egg weight in Indigenous fowls of North-East India under intensive than those under extensive system of rearing. Chatterjee et al., (2007) recorded higher egg weight of the crosses of ILI-80 male x Brown Nicobari female and Brown Nicobari male $\times$ ILI-80 female under intensive than under backyard system of management.

The overall mean shape index value of egg was found to be significantly $(\mathrm{P} \leq 0.05)$ higher for Indigenous $(75.33 \pm 0.31)$ compared to those for Vanaraja (72.38 \pm 0.29$)$ and Crossbred chickens $(70.43 \pm 0.25)$ at 40 weeks of age. Kalita et al., (2011a) and Gonmei (2012) reported higher shape index of Indigenous chicken than Vanaraja. Pathak (2013) recorded significantly $(\mathrm{P} \leq 0.05)$ higher shape index of Indigenous than Crossbred (PB2 $\times$ Indigenous) chicken under deep litter system of rearing.

The overall mean shell thickness values were recorded as $0.335 \pm 0.008,0.380 \pm 0.004$ and $0.383 \pm 0.005 \mathrm{~mm}$ for Indigenous, Vanaraja and Crossbred chicken respectively. The shell thickness of Indigenous chicken egg was found to be significantly $(\mathrm{P} \leq 0.05)$ lower compared to those for Vanaraja and Crossbred chicken at 40 weeks of age. The overall mean yolk index values for Indigenous chicken was found to be significantly $(\mathrm{P} \leq 0.05)$ higher compared to those for Vanaraja and Crossbred chicken at 40 weeks of age. Mathivanan et al., (2001) reported the influence of rearing systems on different egg quality traits.

Doley (2006) recorded significantly $(\mathrm{P} \leq 0.05)$ higher overall egg yolk index under intensive than that of extensive system of rearing. The overall albumen index of different types of chicken did not differ significantly among themselves. Rearing systems also had no significant effect on overall egg albumen index values (Table 1 and Fig. 1). 
Table.1 Mean values various egg quality traits of different types of chicken under intensive and backyard systems of rearing at 40 weeks of age

\begin{tabular}{|c|c|c|c|c|c|c|c|}
\hline $\begin{array}{l}\text { Types of } \\
\text { chicken }\end{array}$ & $\begin{array}{l}\text { Systems of } \\
\text { rearing }\end{array}$ & $\begin{array}{c}\text { Egg } \\
\text { weight } \\
\text { (g) }\end{array}$ & $\begin{array}{l}\text { Shape } \\
\text { index }\end{array}$ & $\begin{array}{c}\text { Shell } \\
\text { thickness } \\
\text { (mm) }\end{array}$ & $\begin{array}{l}\text { Yolk } \\
\text { index }\end{array}$ & $\begin{array}{l}\text { Albumen } \\
\text { index }\end{array}$ & $\begin{array}{c}\text { Haugh } \\
\text { unit } \\
\text { score }\end{array}$ \\
\hline \multirow{3}{*}{ Indigenous } & Intensive & $\begin{array}{l}35.10 \\
\pm 0.38\end{array}$ & $\begin{array}{c}75.58 \\
\pm 0.45\end{array}$ & $\begin{array}{c}0.346 \pm \\
0.008\end{array}$ & $\begin{array}{c}0.474 \\
\pm 0.006\end{array}$ & $\begin{array}{c}0.098 \\
\pm 0.003\end{array}$ & $\begin{array}{r}74.41 \\
\pm 0.75\end{array}$ \\
\hline & Backyard & $\begin{array}{l}34.10 \\
\pm 0.38\end{array}$ & $\begin{array}{c}75.08 \\
\pm 0.43\end{array}$ & $\begin{array}{c}0.323 \pm \\
0.006\end{array}$ & $\begin{array}{c}0.434 \\
\pm 0.006\end{array}$ & $\begin{array}{c}0.093 \\
\pm 0.005\end{array}$ & $\begin{array}{r}72.68 \\
\pm 0.66\end{array}$ \\
\hline & Overall & $\begin{array}{l}34.60^{a} \\
\pm 0.28\end{array}$ & $\begin{array}{l}75.33^{a} \\
\pm 0.31\end{array}$ & $\begin{array}{c}0.335^{a} \\
\pm 0.008\end{array}$ & $\begin{array}{c}0.454^{a} \\
\pm 0.009\end{array}$ & $\begin{array}{c}0.096 \\
\pm 0.003\end{array}$ & $\begin{array}{r}73.54 \\
\pm 0.52\end{array}$ \\
\hline \multirow{3}{*}{ Vanaraja } & Intensive & $\begin{array}{r}54.50 \\
\pm 0.69\end{array}$ & $\begin{array}{l}72.59 \\
\pm 0.41\end{array}$ & $\begin{array}{c}0.395 \pm \\
0.004\end{array}$ & $\begin{array}{c}0.453 \\
\pm 0.004\end{array}$ & $\begin{array}{c}0.108 \\
\pm 0.008\end{array}$ & $\begin{array}{r}79.79 \\
\pm 0.36\end{array}$ \\
\hline & Backyard & $\begin{array}{r}52.80 \\
\pm 0.38\end{array}$ & $\begin{array}{r}72.17 \\
\pm 0.42\end{array}$ & $\begin{array}{c}0.364 \pm \\
0.006\end{array}$ & $\begin{array}{c}0.440 \\
\pm 0.005\end{array}$ & $\begin{array}{c}0.098 \\
\pm 0.003\end{array}$ & $\begin{array}{r}75.42 \\
\pm 0.50\end{array}$ \\
\hline & Overall & $\begin{array}{l}53.65^{b} \\
\pm 0.57\end{array}$ & $\begin{array}{l}72.38^{b} \\
\pm 0.29\end{array}$ & $\begin{array}{c}0.380^{b} \\
\pm 0.004\end{array}$ & $\begin{array}{c}0.427^{b} \\
\pm 0.004\end{array}$ & $\begin{array}{c}0.103 \\
\pm 0.004\end{array}$ & $\begin{array}{l}77.60^{b} \\
\pm 0.59\end{array}$ \\
\hline \multirow{3}{*}{ Crossbred } & Intensive & $\begin{array}{c}45.70 \\
\pm 0.56\end{array}$ & $\begin{array}{r}70.23 \\
\pm 0.31\end{array}$ & $\begin{array}{c}0.398 \\
\pm 0.008\end{array}$ & $\begin{array}{c}0.426 \\
\pm 0.009\end{array}$ & $\begin{array}{c}0.110 \\
\pm 0.008\end{array}$ & $\begin{array}{r}72.62 \\
\pm 0.45\end{array}$ \\
\hline & Backyard & $\begin{array}{r}43.50 \\
\pm 0.48\end{array}$ & $\begin{array}{r}70.64 \\
\pm 0.40\end{array}$ & $\begin{array}{c}0.367 \\
\pm 0.005\end{array}$ & $\begin{array}{c}0.408 \\
\pm 0.004\end{array}$ & $\begin{array}{c}0.097 \\
\pm 0.003\end{array}$ & $\begin{array}{l}71.90 \\
\pm 0.37\end{array}$ \\
\hline & Overall & $\begin{array}{l}44.60^{c} \\
\pm 0.55\end{array}$ & $\begin{array}{l}70.43^{c} \\
\pm 0.25\end{array}$ & $\begin{array}{c}0.383^{b} \\
\pm 0.005\end{array}$ & $\begin{array}{c}0.417^{b} \\
\pm 0.005\end{array}$ & $\begin{array}{c}0.104 \\
\pm 0.006\end{array}$ & $\begin{array}{l}72.26^{a} \\
\pm 0.30\end{array}$ \\
\hline
\end{tabular}

Means with common superscript within a column do not differ significantly $(\mathrm{P} \leq 0.05)$.

Fig.1 Egg weight of different types of chicken at different weeks under intensive and backyard rearing

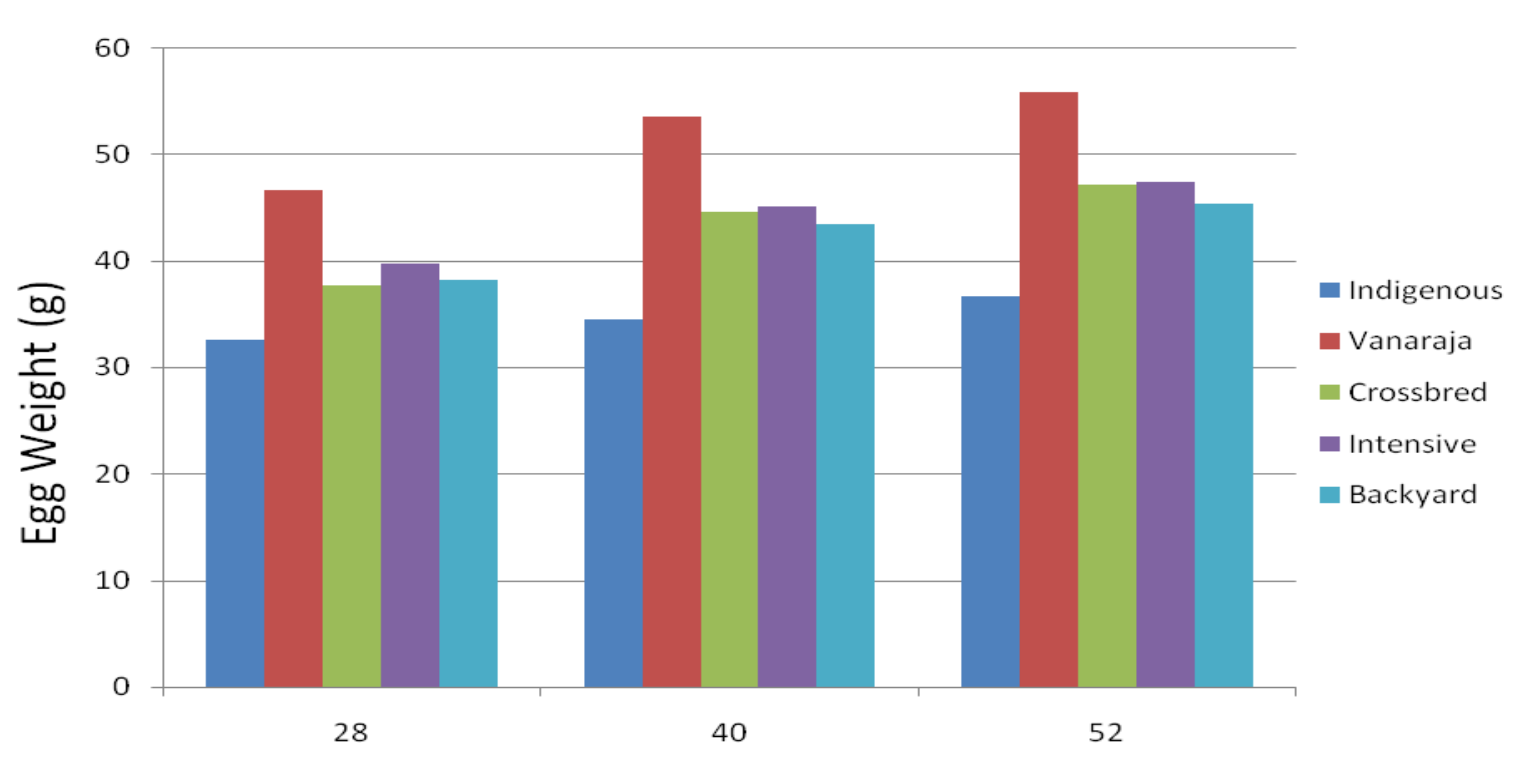


Gonmei (2012) reported non-significant difference between egg albumen index value of Indigenous and Vanaraja chicken. However, Kalita et al., (2011a) recorded significantly $(\mathrm{P} \leq 0.05)$ lower overall egg albumen index in Indigenous than that of Vanaraja chicken. Pathak (2013) recorded significantly $(P \leq 0.05)$ lower overall egg albumen index in Indigenous than that of Crossbred (PB2 x Indigenous) chicken.

This might be due to differences in egg weight which have a positive correlation with albumen index (Sekeroglu and Altuntas, 2009), rearing temperature, relative humidity and season.

The egg albumen index values recorded in the present study were comparable with Buragohain et al., (2006), Baishya et al., (2008), Yadav et al., (2009a) in Indigenous chicken, Gonmei (2012) in Vanaraja chicken. In contrary to the findings of present study, lower egg albumen index were recorded by Parmar et al., (2006) in Kadaknath, Baishya et al., (2008) in Giriraja, Ramana et al., (2010) and Jha et al., (2012) in Vanaraja chicken and Bharambe and Garud (2012) in improved poultry Crossbreds and Vanaraja chicken.

The H.U. score is the measure of albumen quality which determines the quality of the egg. Significant $(\mathrm{P} \leq 0.05)$ differences were observed in overall H.U. scores among the types chicken and rearing systems. Significantly $(\mathrm{P} \leq 0.05)$ higher H.U. scores were observed under intensive system $(75.61 \pm 0.64)$ than backyard system $(73.33 \pm 0.40)$ of rearing. In agreement with the present findings, similar range of scores were reported by some workers (Haunshi et al., 2006; Niranjan et al., 2008 and Jha et al., 2012) in Vanaraja chicken, Parmar et al., (2006) in Kadaknath bird and Yadav et al., (2009a) in backyard chicken.

Significantly $(\mathrm{P} \leq 0.05)$ higher values of egg weight, egg shell thickness, egg yolk index and H.U scores of eggs were observed under intensive system of rearing than those under backyard system of rearing. However, rearing systems had no significant effect on shape index values of eggs. In agreement with the present findings, similar range of scores were reported by some workers (Haunshi et al., 2006; Niranjan et al., 2008 and Jha et al., 2012) in Vanaraja chicken.

From the present study it can be concluded that the Vanaraja had overall better egg qualities in terms of egg weight, albumen index and H.U. score than Indigenous and Crossbred chicken. The Vanaraja could be reared successfully under backyard system of rearing for increasing egg weight and egg numbers. However, crossbred chicken can also be reared under backyard system of rearing for better egg masses than Indigenous chicken under backyard system of rearing.

\section{Acknowledgements}

Authors are highly thankful to the Director of Research (Vety.), Assam Agricultural University, Khanapara, Guwahati for providing necessary facilities to carry out the study.

\section{References}

Baishya, D., Dutta, K.K., Mahanta, J.D. and Borpuzari, R.N. 2008. Studies on certain qualities of different sources of chicken eggs. Tamil Nadu J. Veterinary and Animal Sciences, 4 (4): 139-141.

Basic Animal Husbandry and Fisheries Statistics 2015. Government of India, Ministry of Agriculture and Farmers Welfare. Department of Animal Husbandry, Dairying and Fisheries. Krishi Bhawan, New Delhi.

Bharambe, V.Y. and Garud, P.K. 2012.Comparative performance of some improved poultry crossbreds under Konkan region of India. Journal of Hill Farming, 25(1): 48-52.

BIS.1992. Bureau of Indian Standard of poultry feed. Manik Bhawan, Bahadur Shah Zafer Marg, New Delhi.

Buragohain, R., Saikia, B.N., Barua, K.K. and Konwar, B.K. 2006. Protein and energy levels on laying performance and egg 
quality in indigenous chickens. Indian Vet. J., 83(10): 1129- 1130.

Chatterjee, R.N., Rai, R.B., Pramanik, S.C., Sunder, J., Senani, S. and Kundu, A. 2007. Comparative growth, production, egg and carcass traits of different crosses of Brown Nicobari with White Leghorn under intensive and extensive management systems in Andaman, India. Livestock Research for Rural Development, Vol.19, Article\#193. http://www.lrrd.org//rrd19/12/ chat 19193.htm

Doley, S. 2006. Ph.D Thesis. Assam Agricultural University, Khanapara

Gautam, A. K. 2015. Economic Survey. Vol. 2. https/abhijeetgautam.wordpress.com/ 2015 /06/28/chapter 5 agriculture

Gonmei, G. 2012. M.V.Sc. Thesis, Assam Agricultural University, Khanappara

Haunshi, S., Saxena, S.C., Biswajit, D. and Bujarbaruah, K.M. 2006. Comparative study of certain egg quality traits of Vanaraja and White Leghorn chicken. Indian J. Poult. Sci. 41(3): 323-324.

Jha, D.K., Prasad, S., Soren, S.K. and Mahto, D. 2012. Performance of Vanaraja birds under deep litter system of management. Indian Vet. J., 89(1): 75-76.

Kalita, N., Barua, N., Chutia, H., Islam, R., Pathak, N. and Kalita, R. 2011a. Egg quality and carcass characteristics of Vanaraja and indigenous chicken reared under intensive system. Indian Vet J., 88(10): 66-68.

Khan, A.G. 1996. Krishna J: A coloured dwarf layer for rural and tribal poultry production in India. Proceedings of $10^{\text {th }}$ European Poultry Conference, 21-26 June, 1998, Jerusalem, Israel, 2: 604-606.

Mathivanan, R. Sundaresan, K. and Mani, K. 2001. Effect of drinking water sources and systems of management on egg quality in commercial layers. Indian J. Poult. Sci., 36 (1): 103-105.
Nandi, S., Sharma, K., Pawan, Kumar and Nandi, D. 2007. Poultry farming: A rapidly growing profitable business. Poultry Line, 7(12): 19-20.

Niranjan M., Sharma, R.P., Rajkumar, U., Chatterjee, R.N., Reddy, B.L.N. and Battacharya, T.K. 2008. Egg quality traits in chicken varieties developed for backyard poultry farming in India. Livestock Research for Rural Development, Vol. 20 (12), http://www.lrrd.org/lrrd20/12/nira 20189.htm

Panda, A.K., Raju, M.V.L.N. and Rama Rao, S.V. 2008. Poultry Production in India: Opportunities and Challenges Ahead. Poultry Line, 8(1): 11-14.

Parmar, S.N.S., Thakur, M.S., Tomar, S.S. and Pillai, P.V.A. 2006. Evaluation of egg quality traits in indigenous Kadaknath breed of poultry. Livestock Research for Rural Development, Volume 18, http:// www.lrrd.org/ lrrd18/9/ parm18132.htm

Pathak, S.S. 2013. M.V.Sc. Thesis, Assam Agricultural University, Khanapara

Ramana, D.V.B., Nirmala, G., Maruthi, V. and Rap, G.R. 2010. Performance of Vanaraja birds as backyard poultry. Indian Vet. J., 87(5): 517- 518.

Sekeroglu, A. and Altuntas, E. 2009. Effects of egg weight og egg quality characteristics. Journal of Science of Food and Agriculture, 8(3): 379-383.

Snedechor G. W. and Cochran W. G. 1994. Statistical methods, $6^{\text {th }}$ edn., Oxford and IBH Publishing Co., Calcutta.

Tajane, S.B. and Vasulkar, R. 2014. Development of rural backyard poultry. Poultry Punch, 30(3): $30 \& 35$.

Yadav, S.N., Kumar, Y., Singh, B., Ghosh, A.K. and Kaur, N. 2009a. Evaluation of egg quality traits of chicken reared under backyard system in western Uttar Pradesh. Indian J. Poult. Sci., 44(2): 261-262.

\section{How to cite this article:}

Sheikh, I.U., N. Kalita, J.D. Mahanta and Hussain, J. 2018. Studies on Certain Egg Qualities of Indigenous, Vanaraja, and Crossbred (PB2 x Indigenous) Chickens under Intensive and Backyard Systems of Rearing. Int.J.Curr.Microbiol.App.Sci. 7(04): 1690-1695.

doi: https://doi.org/10.20546/ijcmas.2018.704.191 